УДК 304.2

DOI: 10.18101/1994-0866-2019-2-49-56

\title{
ГЕНЕЗИС И ЭВОЛЮЦИЯ ФАНАТИЗМА
}

\author{
(C) Ким Виктория Валентиновна \\ кандидат философских наук, доцент, \\ Амурский гуманитарно-педагогический государственный университет \\ Россия, 681000, г. Комсомольск-на-Амуре, ул. Кирова, 17/2 \\ E-mail: vkv-viktory@mail.ru
}

В статье исследуются условия формирования фанатизма в сфере религии, определяются тенденции в эволюции религиозных институтов, способствующие производству фанатизма. Автор обращает внимание на внутренние процессы становления и развития разных религий (политеистических: египетского и римского язычества; монотеистических: иудаизма, христианства, ислама); на политические и экономические факторы религиозных изменений, в которых проявлялся религиозный фанатизм. В статье показано, что производство религиозного фанатизма является закономерным и востребованным процессом в разные этапы эволюции религиозных структур, может носить охранительный, интегрирующий и иной характер. Установленные исторические тенденции в производстве религиозного фанатизма не теряют своей актуальности в современном обществе: в эпоху религиозного ренессанса конфессиональные диалоги сменяются конфликтами, прозелитизм представителей мировых религий соседствует с пропагандистской деятельностью нетрадиционных религиозных движений и культов, к религиозным аргументам прибегают не только политики, но и террористы, все названное свидетельствует в пользу того, что ресурсы производства религиозного фанатизма еще не исчерпаны.

Ключевые слова: религия; религиозный фанатизм; история религии; институционализация религии; нетерпимость; догматизм.

\section{Для цитирования:}

Ким В. В. Генезис и эволюция фанатизма // Вестник Бурятского государственного университета. Философия. 2019. Вып. 2. С. 49-56.

Самым распространенным видом фанатизма в обществе является религиозный, зачастую проявляющийся не только в сфере религии, но и политики. В эпоху «нового средневековья» [14], когда религия возвращается в политическую жизнь, становится еще более актуальным обращение к анализу условий производства фанатизма в религии, в первую очередь к тем внутренним процессам религиозного развития, которые стимулируют проявления нетерпимости и фанатизма. Последних можно увидеть в процессе эволюции от политеизма к монотеизму, в периоды кристаллизации основных религиозных догматов и борьбы с вероотступниками (сектантами и еретиками), при формировании принципов религиозной терпимости и многих других.

Многие страны древности были полиэтничны и поэтому терпимы по отношению к иным этносам и их богам. Главы пантеонов - Зевс, Юпитер, Перун, Один и прочие - обладали большей властью и возможностями по сравнению с другими. Но почитание богов в язычестве не знало ревности, люди приносили жертвы, совершали ритуалы, выделяя некоторых богов как более значимых для себя, не забывая остальных. Основной добродетелью гражданина государства этого пе- 
риода было почитание богов, и такая религиозная политика существовала так долго, пока не стала приносить больше вреда, нежели пользы. Язычество достаточно эффективно функционировало в условиях существования одного народа в стране, когда система верований не вступала в противоречия с верованиями других народов. На примере двух империй - египетской и римской - видно, каким образом язычество и последующее введение монотеизма повлияли на формирование фанатизма.

Введение монотеизма в период правления Аменхотепа IV (XIV в. до н. э.) было связано с расширением территорий Египта, необходимостью укрепить власть египетских богов на новых землях и проникновением на египетские земли иноземных традиций и верований. Фараон поменял имя на Эхнатон и начал политику последовательного установления культа единого бога Атона в стране: закрывались храмы, запрещались прежние богослужения, конфискации подлежало имущество храмов, «...рвение было так велико, что были подвергнуты осмотру даже древние памятники, чтобы стереть с них слово «бог», когда оно встречалось во множественном числе» [9], из новой религии было исключено все, что было связано с магией, колдовством и мифами. Нетерпимость и фанатизм служителей нового культа сталкивались с сопротивлением, которое в полной мере проявилось после смерти Эхнатона. В данном случае монотеизм стал следствием политического и экономического развития страны, способствовал началу и углублению кризиса, расколов страну на две части, и в конечном итоге привел к упадку династии, а Эхнатон был объявлен преступником, Египет вернулся в прежние границы и к прежним верованиям. Попытки религиозной реформы в виде введения монотеизма для египетского общества были преждевременными, они вступили в противоречие с существующими традициями и обычаями политеизма.

Свой путь к монотеизму прошла и Римская империя, остававшаяся духовно целостной и организационно устойчивой до тех пор, пока не стала увеличиваться, включая в свой состав представителей завоеванных народов вместе с их верованиями. В этих условиях политеизм становился непродуктивным инструментом консолидации империи и постепенно начал уступать господствующие позиции монотеистическим верованиям - правда, происходило это постепенно и незаметно для римлян. Почитание богов римского пантеона было обязанностью гражданина и считалось основой патриотизма, нарушение этого правила являлось государственным преступлением и каралось по закону. Постепенно в Риме стали преследовать за иную веру, что особенно ярко проявилось с распространением христианства среди населения и отказом христиан принять основной принцип политической власти - культ императора как божества (гонения на христиан стали хрестоматийным сюжетом римской истории, их распинали на крестах, бросали в клетки ко львам, сжигали и т. д.). Нетерпимость и фанатизм стали признаками этих процессов - с одной стороны, римляне, которые в преследовании тех, кого считали преступниками, иногда превышали меру, излишне жестоко преследовали инакомыслящих; с другой стороны, христиане проявляли в вере упорство, одержимость, что нередко приводило к трагическому финалу.

Таким образом, многобожие потенциально несло в себе «заряд» распада полиэтничного и поликонфессионального государства: возникало множество вопросов в связи с преследованием представителей иных культов [4, с. 45-53]. Для 
скрепления государства требовалось что-то менять, римские боги так и не стали богами бывших варваров - новых римлян, продолжавших поклоняться тайно или явно прежним богам. Выходом стало принятие Миланского эдикта о веротерпимости при императоре Константине (313 г.), постепенное распространение христианства в качестве основной веры и установление его как государственной религии в 391 г. при императоре Феодосии. Это способствовало объединению переживающей кризис Римской империи (к концу IV в. христианство было принято практически на всех территориях Римского государства). Рим стал монотеистичным, но для окончательной христианизации требовалось время. Таким образом, переход к монотеизму стал условием производства фанатизма, как в среде сторонников монотеизма, так и среди его противников, и эта тенденция наблюдалась и в других государствах.

Она была зафиксирована и в основных текстах мировых религий (Библии и Коране), где подчеркивалась роль религии как социального института в истории народов, в частности евреев и арабов. История этнических общностей, изложенная в текстах Ветхого Завета и Корана, позволила сделать вывод об интегрирующей роли фанатизма в их становлении. Отцом, покровителем и судьей евреев стал бог иудаизма - Яхве, от его имени священнослужители призывали уничтожать иноверцев: А в городах сих народов, которых Господь ... дает тебе во владение, не оставляй в живых ни одной души, но предай их заклятию: хеттеев и амереев, и хананеев..., дабы они не научили вас делать такие же мерзости, какие они делали для богов своих... ${ }^{1}$. Борьба с другими верованиями стала способом консолидации общества и механизмом защиты веры. У иудаизма была также функция объединения людей и племен одной языковой группы на религиозной основе, выполнению этой функции способствовал фанатизм. Иудеи не раз становились объектом пристального внимания завоевателей (египтян, римлян), что требовало от них особых усилий по сохранению этнической идентичности, в том числе и непримиримого отношения к иным верованиям. Тем самым фанатичная нетерпимость, которую проявляли иудеи, была своеобразной защитной реакцией. Этой же цели служили отстаивание традиций и обычаев, поскольку фанатичное слежение за сохранением идентичности способствовало выживанию небольших этносов. Схожий процесс сохранения идентичности был характерен для арабов в первых веках н.э., когда кочующие племена должны были объединиться по языковому и религиозному признакам, чтобы не допустить растворения в других народах.

Таким образом, условием производства фанатизма стала потребность становящихся этносов в сохранении идентичности на основе религии, что свидетельствовало о формировании этноконфессионального фактора политики (монотеизм евреев и арабов в сочетании с политикой стал дополнительным стимулом для нетерпимости и фанатизма).

Фанатизм проявился и в условиях борьбы с инаковерующими при становлении христианства как мировой религии и церкви как социального института. Борьба с арианством и другими ересями показала, что основной задачей церкви стала борьба с инаковерующими. Этот процесс начался еще при Константине и продолжался много веков, сопровождаясь всплесками религиозного фанатизма.

\footnotetext{
${ }^{1}$ Библия. М., 1976. С. 189.
} 
Утверждение ортодоксии приводило к некоторому «консервированию» веры и вместе с тем вызывало у части верующих вопросы об истинности установленных догматов, правильности официальной трактовки, в итоге появлялась потребность дать свой ответ на поставленные вопросы, что становилось причиной для оформления ереси - а это уже инаковерие, которое церковь не могла допустить. Одной из основных тенденций развития церкви было перманентное появление ересей и последовательная борьба с ними. В этом процессе фанатизм проявляли обе стороны: церковники с одержимостью преследовали еретиков, поскольку опасны не внешние враги (которые находились за пределами церковного влияния и становились причинами для объявления войн), а внутренние, т. к. появление ересей было симптомом кризиса, чревато расколом общества и потерей авторитета церкви; в свою очередь еретики представляли собой новообращенных, неофитов, которые только что обрели истинную веру и готовы были отстаивать ее даже ценою жизни, отступление от веры им казалось предательством. Распространенным видом казни времен инквизиционных преследований еретиков были аутодафе - сжигание на костре (для еретиков он был актом мученичества, который в последний раз подтверждал истинность веры, а для инквизиторов он служил своеобразным актом спасения еретиков, считалось, что в пламени огня душа еретика очистится от греховных помыслов и он сможет спастись).

Причиной фанатизма становилось и религиозное рвение, которое нередко проявляли верующие, оно умело направлялось (фанатизм был нужен во время крестовых походов, в борьбе с еретиками и ведьмами, использовался как основание для террора). Часто поводом для проявления фанатизма становилось толкование текстов священных книг, посланий бога идеологами в духе нетерпимости, что считалось прямым указанием к действию - насильственному обращению или уничтожению всех инаковерующих [радикально-экстремистское прочтение текстов Корана характерно для исламских фундаменталистов: 6; 8]. В итоге идеологическое манипулирование с помощью религиозных (священных) текстов, в сочетании с призывами к истреблению «чужих» стало инструментом производства фанатизма.

Религиозный фанатизм может возникнуть и на почве служения, когда человек чувствует потребность выражать свою преданность намного чаще и сильнее, чем все остальные верующие. Например, в Палестине исступленно верующих мусульман отличают по потемневшей и ороговевшей коже на лбу из-за ударов лба о камень во время молитвы, что является свидетельством ревностной веры; если обычный мусульманин посещает мечеть 1-3 раза в неделю, то неистово верующий молится в мечети минимум 5 раз в неделю, ежедневно и даже по два раза в день [12]. Здесь фактором производства фанатизма является внутренняя потребность в вере, рождающая исступленную преданность, одержимость, нетерпимость к тем, кто не верит в твоего бога.

Религия как тип мировоззрения содержит нормы и правила, которые должны тщательно исполняться верующим, например, в Библии содержится следующий принцип абсолютного послушания: «... поступайте так, как повелел вам Господь..., не уклоняйтесь ни направо, ни налево, ходите по тому пути, по которому 
повелел вам Господь...» ${ }^{1}$. В результате может наблюдаться несколько вариантов поведения человека:

- полное повиновение, при котором слово Бога трактуется буквально и становится руководством к действию;

- полное неприятие данного требования, поиск собственных мировоззренческих оснований с помощью критического мышления;

- видимость следования установленным нормам при независимом мышлении, возможна пассивная или активная позиция бунтаря или скептика.

Все названные варианты содержат в себе потенцию к фанатизму. Первый изза догматического восприятия информации, убежденности в истинности веры и готовности к проявлению нетерпимости. Второй - это тип революционера и атеиста, который в чрезвычайных кризисных ситуациях может стать фанатиком на почве абсолютизации самой идеи критики религии. Третий способен стать фанатиком в результате заражения в массе на некоторый временной промежуток, в случае распада массы и наступления социальной стабильности этот эффект обнуляется.

Как уже говорилось, религиозность общества в сочетании с идеологией способствовала более легкой управляемости. Защита веры становилась делом государственной важности. Еще в Византии император Феодосий (IV век) стал считать основным долгом христианского правителя «привести всех своих подданных к истинной вере с помощью мер государственного принуждения» $[4$, с. 88], что вызвало массовые гонения на нехристиан (к примеру, еврейские погромы). Сотрудничество государства и церкви продолжилось и в Средние века. Так, во время деятельности института Инквизиции судебное заседание и вынесение приговора были делом инквизиционного суда, а наказание виновных грешников делом государства, поскольку в случае доказательства виновности церковь лишала грешника божественного покровительства и передавала его в руки правосудия. Суды над тамплиерами, крестовые походы против еретиков, охота на ведьм - все это яркие страницы истории инквизиции, в которых участники процессов проявляли фанатизм или использовали его как инструмент воздействия на людей.

Продуцирование фанатизма было связано также с решением вопросов экономической жизнедеятельности, расширения территорий и усиления политического влияния в интересах церкви. Хрестоматийным примером такого взаимовыгодного сотрудничества церкви и государства был процесс над самым богатым духовно-рыцарским орденом того времени - орденом тамплиеров, который инициировали Папа римский и король Франции. Процесс был также показательным для остальных с целью устранения «соперников», т. к. тамплиеры завоевывали все больший авторитет среди простого населения. Фабрикация процесса включала в себя обвинение в ереси и других грехах, поклонение дьяволу, разные извращения и т. д. В результате имущество ордена было конфисковано, наиболее известные тамплиеры сожжены, а остальные подвергались преследованию, многие в поисках убежища покинули Францию. Многочисленные крестовые походы против мусульман и еретиков также обогащали церковь, поскольку имущество грешников подлежало конфискации [3; 7]. Крестовые походы служили также цели ду-

\footnotetext{
${ }^{1}$ Библия. М., 1976. С. 175.
} 
ховного обновления, повышения значимости веры и церкви для прихожан, для этих же целей церковь способствовала возникновению фанатизма с помощью экзальтированных проповедников. Таким образом, зачастую религиозные вопросы служили своеобразным «прикрытием» частных корыстных интересов церковного руководства. А для многих рядовых священнослужителей вера и познание бога становились предметами фанатичного интереса, они усердно изучали священные тексты, занимались их трактовкой, отстаивая в теологических спорах свое понимание, часто проявляя исступление и энтузиазм.

Фанатизм был востребован также в период истории христианства, связанный с секуляризацией и формированием атеизма. Начало секуляризации связано с Реформацией, которая, боровшись за обновление церкви, невольно способствовала подрыву ее авторитета. Уменьшение религиозного влияния шло постепенно, приняв в середине XIX в. характер устойчивой тенденции. Церкви пытались противостоять этому процессу, усиливая духовное давление на прихожан, изобретая способы и методы привлечения новых верующих, одновременно осуществляя атаки на атеистов и их идеологов. Вместе с тем атеизм у многих приобретал характер новой веры [например, у русских интеллигентов XIX - начала XX в., по мнению авторов сборника «Вехи» $\left.{ }^{1}\right]$ и способствовал формированию фанатизма. Преследование верующих как инакомыслящих было и в советское время, с распадом Советского Союза начался активный процесс десекуляризации, освободившиеся ниши старались занять не только представители официально признанных в РФ религий, но и многочисленные миссионеры разных конфессий.

В современном мире действуют тенденции, вызванные секуляризацией [2; 11]: углубление секуляризации под влиянием научно-технического прогресса и распространение информационных технологий [10], вместе с тем происходит усиление интереса к религиям, различным духовным практикам, данный процесс получил название «религиозный ренессанс». Число верующих в мире за последние 100 лет растет: мусульман стало больше в 5 раз (с 216 до 1180 млн), индуистов в 4 раза (с 223 до 888 млн), сикхов (с 4,5 до 23 млн), джайнов (с 1 до 4 млн) [4, с. 374]. Активизируются миссионеры традиционных религий в странах Африки и Азии, что подчас вызывает столкновения между сторонниками христианства и ислама, нетерпимость и фанатизм верующих (в условиях насильственного преследования усиливается их энтузиазм и экзальтированность). В Африке продолжается война за духовное господство, соперничество между христианством и исламом за «души» с переменным успехом. Число мусульман на этом континенте растет, религиозный состав в 2000 г. таков: $40 \%$ мусульман, $30 \%$ христиан (из них $10-12 \%$ католики, $10 \%$ протестанты, $8-10 \%$ монофизиты, православные и др.), $30 \%$ - остальные. Важнейшим стимулом к исламизации африканских стран является экономический, который возможен благодаря богатым нефтедобывающим исламским странам, предлагающим гранты и беспроцентные кредиты государствам, чьи граждане исповедуют ислам (в Мали до независимости было $30 \%$ мусульман, после - 90\%). К тому же особенностью исламского миссионерства в Африке является то, что миссионером становится африканец в отличие от христианских миссионеров, что способствует росту популярности религии (согласно

1 Вехи: сб. ст. о русской интеллигенции [Электронный ресурс]. M., 1909. URL: http://www.vehi.net/vehi/index.html (дата обращения: 01.12.2018). 
прогнозам, через 20-30 лет Африка станет исламской) [5]. Ливийский исламский ученый и директор центра по подготовке имамов и проповедников Корана шейх Ахмад Аль-Катаани в 2006 г. в интервью телеканалу Аль-Джазира представил такие цифры: «Только в Африке каждый час 667 мусульман принимают христианство, 16 тыс. - каждый день, 6 млн - ежегодно» ${ }^{1}$. Такое состояние дел не устраивает радикальных исламских фундаменталистов и становится причиной преследования христиан, обоснованием терактов ${ }^{2}$, в частности в Нигерии, Эфиопии, Сомали и других странах.

Сопровождается религиозный ренессанс и возникновением нетрадиционных деструктивных культов $[1 ; 14]$ на основе традиционных религий, мифологии, науки, эзотерики, психологических и мистических практик и т. п. Зачастую лидеры этих культов целенаправленно формируют и эксплуатируют фанатизм у последователей, удовлетворяя свои социально-экономические потребности. Иногда фанатизм культистов приводит к совершению массовых самоубийств, кровавых акций и т. д. И еще одной современной тенденцией становится ответная реакция на секуляризацию в виде политизации религии, возникновения религиозного фундаментализма, проявления экстремизма и терроризма в этноконфессиональных конфликтах.

Исходя из вышесказанного, религия является самой благодатной сферой жизнедеятельности общества для формирования нетерпимости и фанатизма. Его производство и воспроизводство возможно в следующих условиях: борьбы с инакомыслящими и инаковерующими; при сочетании религиозного рвения, исступления, одержимости, фанатичных веры и энтузиазма; развития монотеизма и последующего преследования представителей других вер; действия этноконфессионального фактора (интегрирующей функции религии) в процессе этнического строительства с целью сохранения этнической идентичности; сотрудничества церкви с государством; идеологической эксплуатации веры (манипулировании религиозными текстами); исполнения/неисполнения принципа абсолютного послушания в религии; секуляризации и последующего возникновения атеизма, деструктивных культов, фундаментализма и связанных с ним экстремизма и терроризма; многие из названных условий актуальны и сегодня.

Литература

1. Балагушкин Е. Г. Живительный эликсир или опиум прокаженного? Нетрадиционные религии, секты и культы в современной России. M.: URSS, Либроком, 2014. 256 с.

2. Корм Ж. Религиозный вопрос в XXI в. Геополитика и кризис постмодерна. М.: Изд-во Ин-та общегуманитарных исследований, 2012. 288 с.

3. Ли Ч. История инквизиции в Средние века. Смоленск: Русич, 2001. 635 с.

4. Логинов А. В. Власть и вера: государство и религиозные институты в истории и современности. М.: Большая Российская энциклопедия, 2005. 496 с.

${ }^{1}$ Ежегодно 6 млн мусульман Африки принимают христианство [Электронный ресурс] // Христианин. 2013. 7 марта. URL: http://news.christian.by/world/2892-ezhegodno-6mln-musulman-afriki-prinimayut-xristianstvo.html (дата обращения: 01.12.2018).

2 География и статистика гонений на христиан в странах Африки // Гонения на христиан: анализ, история происхождения и география гонений на христиан в разных странах и регионах [Электронный ресурс]. 2012. 30 марта. URL: http://persecutionchrist.wordpress.com/category/страны-африки/ (дата обращения: 10.12.2018). 
5. Логинов Е. Ислам в Африке [Электронный ресурс] // Центр стратегических оценок и прогнозов. 2013. 24 янв. URL: http://www.csef.ru/index.php/ru/politica-igeopolitica/project/326-russias-future-and-the-world-population-estimate/1-stati/3937-islam-vafrike (дата обращения: 10.12.2018).

6. Маммадов Э. «Исламский фундаментализм» как политико-идеологический проект [Электронный ресурс] // Электронный минбар. 2016. 11 авг. URL: https://eminbar.com/researches/islamskij-fundamentalizm-kak-politiko-ideologicheskij-proekt (дата обращения:12.01.2018).

7. Ольденбург 3. Костер Монсегюра. История альбигойских крестовых походов. СПб.: Алетейя, 2001. 416 с.

8. Семашко И. М. Современный исламский фундаментализм: «La Revanchede Dieu» и/или альтернативный проект глобализации? // Вестник Волгоградского государственного университета. Сер. 7. Философия. 2011. № 1(13). С. 101-105.

9. Фрейд 3. Моисей и монотеизм [Электронный ресурс] // Библиотека Гумер. URL: http://www.gumer.info/bibliotek_Buks/Psihol/Fr_Mois/02.php (дата обращения: 11.12.2018).

10. Фромм Э. Иметь или быть. М.: АСТ, 2000. 448 с.

11. Харрис С. Конец веры. Религия, террор и будущее разума. М.: Эксмо, 2011. 496 с.

12. Шойбле М., при участии Циолковски Б. Джихад. Террористами не рождаются. М.: КомпасГид, 2012. 256 с.

13. Эко У. Средние века уже начались [Электронный ресурс] // Anthropology. URL: http://anthropology.ru/ru/text/eko-u/srednie-veka-uzhe-nachalis (дата обращения: 12.01.2018).

14. Яковлева Ю. А. Социологический анализ нетрадиционных религиозных сообществ: теоретико-методологический аспект // Государство, религия, церковь в России и за рубежом. 2011. № 2. С. 133-149.

\section{GENESIS AND EVOLUTION OF FANATICISM}

\section{Viktoriya V. Kim}

Cand. Sci. (Philos.), A/Prof.,

Amur State University of Humanities and Pedagogy

17/2 Kirova St., Komsomolsk-on-Amur, Russia

E-mail: vkv-viktory@mail.ru

The article deals with the conditions for emergence of fanaticism in the sphere of religion over the span of history, identifies trends in the evolution of religious institutions that contribute to the development of fanaticism. We pay special attention to the internal processes of becoming and development of different religions (polytheistic - Egyptian and Roman Paganism; monotheistic - Judaism, Christianity, Islam), the political and economic factors of religious fanaticism. The article shows that development of religious fanaticism is a naturally determined and requested process at different stages of the evolution of religious structures, and it can be protective, integrating or have another character. The historical currents of religious fanaticism development do not lose their relevance in modern society: confessional dialogues in the era of religious renaissance are replaced by conflicts; proselytism of the representatives of world religions coexists with the propaganda activities of non-traditional religious movements and cults; not only politicians but also terrorists resort to religious arguments. All this testifies in favor of the fact that the resources of religious fanaticism have not been exhausted.

Keywords: religion; religious fanaticism; the history of religion; institutionalisation of religion; intolerance; dogmatism. 